\title{
CORAL REEF DETECTION USING SAR/RADARSAT-1 IMAGES AT COSTA DOS CORAIS, PE/AL, BRAZIL
}

\author{
Frederico de Moraes Rudorff and Douglas Francisco Marcolino Gherardi \\ Instituto Nacional de Pesquisas Espaciais - INPE \\ Divisão de Sensoriamento Remoto \\ (Avenida dos Astronautas, 1.758, 12227-010 São José dos Campos, SP, Brasil) \\ fmr@dsr.inpe.br, douglas@dsr.inpe.br
}

\begin{abstract}
The present work aimed to examine the potentials of SAR RADARSAT- 1 images to detect emergent coral reefs at the Environmental Protection Area of "Costa dos Corais". Multi-view filters were applied and tested for speckle noise reduction. A digital unsupervised classification based on image segmentation was performed and the classification accuracy was evaluated by an error matrix built between the SAR image classification and a reference map obtained from a TM Landsat-5 classification. The adaptative filters showed the best results for speckle suppression and border preservation, especially the Kuan, Gamma MAP, Lee, Frost and Enhanced Frost filters. Small similarity and area thresholds ( 5 and 10 , respectively) were used for the image segmentation due to the reduced dimensions and the narrow and elongated forms of the reefs. The classification threshold of $99 \%$ had a better user's accuracy, but a lower producer's accuracy because it is a more restrictive threshold; therefore, it may be possible that it had a greater omission on reef classification. The results indicate that SAR images have a good potential for the detection of emergent coral reefs.
\end{abstract}

\section{RESUMO}

O presente trabalho examinou o potencial de imagens SAR do RADARSAT-1 na detecção de recifes de coral expostos na Área de Proteção Ambiental das Costa dos Corais. Filtros de multi-visada foram aplicados e testados para redução do ruído speckle. Uma classificação não supervisionada baseada em uma imagem segmentada foi realizada e a acurácia da classificação foi avaliada através de uma matriz de erro construída entre a imagem classificada e o mapa de referência. Os filtros adaptativos apresentaram os melhores desempenhos para supressão de speckle e preservação de bordas, especialmente os filtros Kuan, Gamma MAP, Lee, Frost and Enhanced Frost. Os pequenos limiares de similaridade e de área (10 e 5 , respectivamente) foram melhores devido à forma fina e alongada dos recifes. O limiar de classificação de $99 \%$ apresentou uma melhor acurácia do produtor, mas uma menor acurácia do usuário, porque este limiar é mais restritivo; portanto, é possível que tenha havido uma maior omissão na classificação de recifes. Os resultados indicam que imagens SAR têm um bom potencial para a detecção de recifes expostos.

Descriptors: Coral reefs, SAR images, Detection, Costa dos Corais.

Descritores: Recifes de coral, Imagens SAR, Detecção, APA Costa dos Corais.

\section{INTRODUCTION}

Coral reef mapping has various uses, including navigation, research, coastal management, economic exploitation, coastal defense, amongst others (YAMANO et al., 2006). In Brazil, these ecosystems are of great economic importance, since they are exploited for fisheries by many traditional communities that depend on fishing (MOBERG; FOLKE, 1999) and for tourism. Besides having great biodiversity and high biological productivity, coral reefs also act as natural breakwaters, protecting the coast from erosion and damages caused by storm waves (CLARK, 1996). They are also a threatened ecosystem, especially by predatory activities and coral bleaching.

In Brazil, reefs extend discontinuously for about 2,400 km along the Brazilian coast, from the Parcel de Manuel Luís, Maranhão State (about $1^{\circ} \mathrm{S}$ ) down to Arraial do Cabo, Rio de Janeiro State (about $23^{\circ} \mathrm{S}$ ), including oceanic islands, such as Atol das Rocas and Fernando de Noronha (CASTRO; PIRES, 2001). Due to the lack of information on Brazilian reefs, and their biota, detailed coral reef mapping is considered as a priority (CASTRO; PIRES, 2001).

According to BRAGA and GHERARDI (2001), researches on coral reefs have been realized through orbital remote sensing since the late seventies of the past century. The use of this technology has 
advanced significantly with the development of new sensors (KUCHLER et al., 1986). However, there are limitations to the use of optical systems which operate on the visible and infrared regions of the electromagnetic spectrum, such as: $\mathrm{TM}, \mathrm{ETM}^{+}, \mathrm{HRV}$, photographic cameras, high resolution sensors, amongst others (AHMAD; NEIL, 1994; ANDRÉFOUËTA et al., 2003; GREEN et al., 2000; PURKIS, 2005; RIEGL; PURKIS, 2005; SHERBININ et al., 2002; STOFFLE et al., 1994).

In the late 90 's, with the commercialization of orbital images generated by SAR (Synthetic Aperture Radar) sensors, such as ERS, JERS and RADARSAR-1, a new range of application for the earth's surface appeared, including for the coastal zone.

The SAR is a radar imaging system, by which a synthetic aperture is simulated by the movement of the carrying platform. Thus, the sensor emits a series of signals on the target's direction, maintaining it on the antenna's beam. The microwaves carry with them information such as wave direction, phase, polarization, length and frequency (LILLESAND KIEFER, 2000). The signals are then processed, generating an image. The maximum size of the synthetic aperture for a specific point is determined by the time the same point remains inside the real beam of the radar (LILLESAND; KIEFER, 2000).

Important applications of SAR images in oceanography include detailed determination of wind field pattern, wave direction and length; monitoring of the migration of shallow water sand banks, and detection of coast line (JOHANNESSEN et al., 2000); almost real time monitoring of oil spills (SOLER, 2000); mangrove mapping on tropical environments, mapping of environmental sensitivity, inundation modeling, ship detection (GALY; SANDERS, 2002; GREEN et al., 2000; VAN DER SANDEN; ROSS, 2001); and mapping of aquaculture and fishing structures (TRAVAGLIA et al., 2004).

YAMANO et al. (2006) evaluated various satellite optical sensors for waterline extraction of coral reefs, and highlighted that despite the fact that SAR images have not yet been used for coral reef mapping, SAR sensors can be an attractive option, especially on tropical areas.

The mapping of emergent reefs through SAR images is based on the high contrast of the backscattered signal between land and aquatic environments. The air/water interface behaves as a flat surface reflecting the microwave energy away from the sensor causing it to appear with dark tonalities on SAR images. However, terrestrial environments are considered to be rough, producing a diffuse backscattering, and appearing on medium to bright gray tonalities on the same images. Therefore, it is expected that the emergent coral reef features such as reef crest and reef flat can be successfully detected by SAR images.

In the present work we assess the potential of SAR/RADARSAT-1 fine mode images for the detection of emergent coral reef features of the Costa dos Corais Environmental Protection Area.

\section{Material and Methods Study Area}

The Environmental Protection Area (EPA) of Costa dos Corais (from $8^{\circ} 45^{\prime} \mathrm{S}, 34^{\circ} 30^{\prime} \mathrm{W}$ to $9^{\circ} 25^{\prime} \mathrm{S}$, $35^{\circ} 30^{\prime} \mathrm{W}$ ) is situated on the Northeastern Coast of Brazil (Fig. 1) and was implemented by the Brazilian government in 1997. It is the country's largest federal marine conservation unit, enclosing an area of 4,590 $\mathrm{km}^{2}$ that crosses 12 counties, from Paripueira, Alagoas State (AL) to Tamandaré, Pernambuco State (PE).

According to MAIDA and FERREIRA (1997), the coral reefs encountered on the EPA's area are formed by three lines parallel to the coastline. The inner line is formed by beachrocks that remain exposed during low tides and support great amounts of macroalgae. The second line is characterized by calcareous algae, and the outermost line is formed by zoanthids at deeper waters, which in some cases can be exposed. Most reef flats are intertidal and remain exposed at low tide (MORELLI, 2000). The tide is semidiurnal and has a range of approximately $2.3 \mathrm{~m}$.

Data Set

The SAR/RADARSAT-1 image was acquired on December $22^{\text {nd }}, 2001$ at 18:49. The image was on CEOS RADARSAT 16 bit format, fine beam mode (F3) in the ascending orbit (east facing), and registered using the UTM projection and the horizontal datum SAD69. The beam mode defines the area it covers and the spatial resolution available (RSI, 1997). The fine mode is one of the 7 beam modes available from RADARSAT-1, having the highest nominal range and azimuth resolution $(6$ and $8.9 \mathrm{~m}$, respectively) and the smallest swath width $(50 \mathrm{~km})$. The RADARSAT-1 fine mode images can also be acquired in 5 beam positions that correspond to the incident angle position in degrees, being F1 the shallowest angle and F5 the steepest. The image used on the present research was acquired with the F3 incident angle $\left(41-44^{\circ}\right)$. According to the tide forecast available at the Brazilian National Oceanographic Database (BNDO), the tide level at Porto de Suape, situated about $40 \mathrm{~km}$ south of Recife, PE, was $1.39 \mathrm{~m}$ during the image acquisition. 

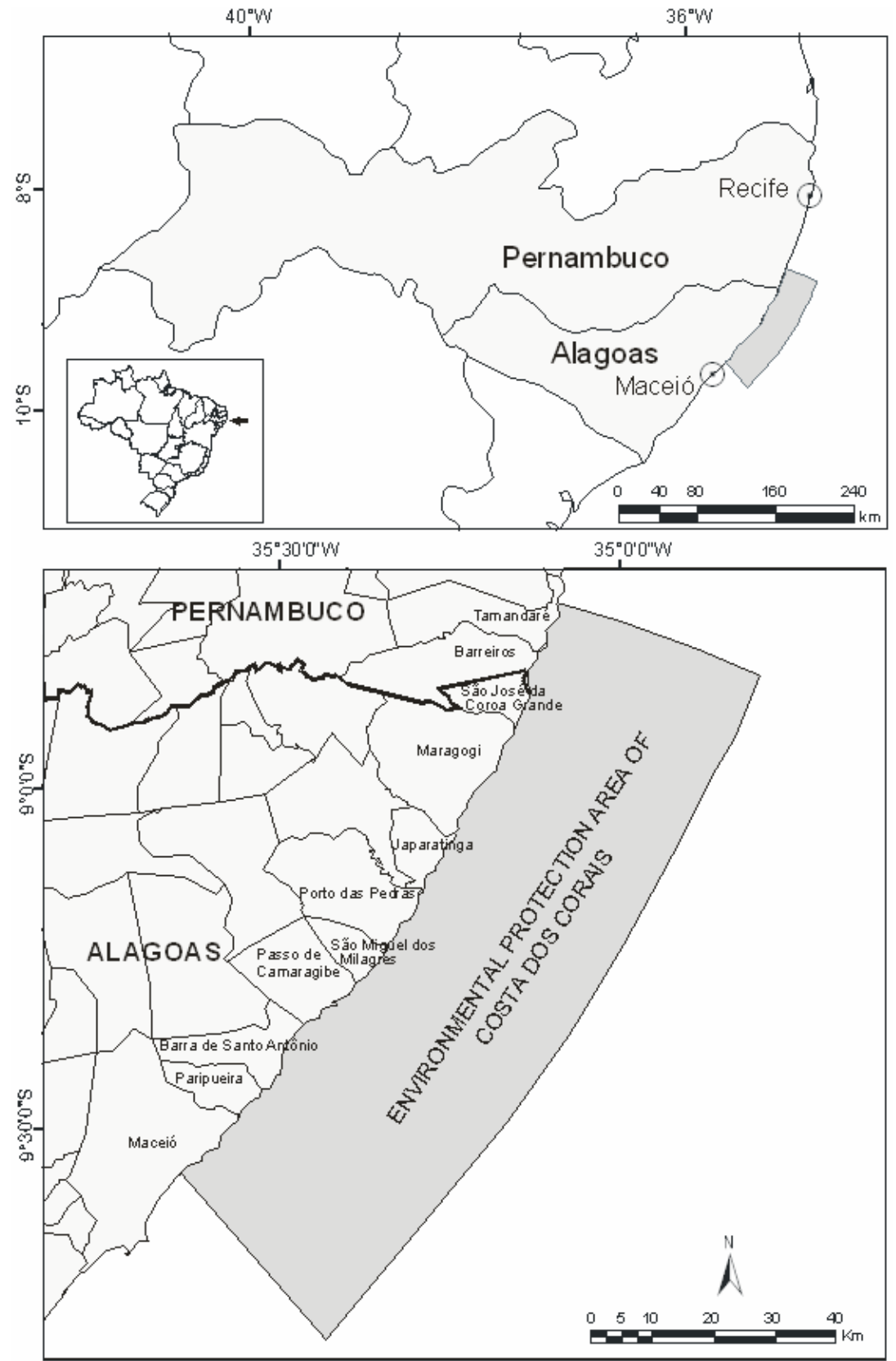

Fig. 1. Location of the study site.

Ground truthing was derived from a classified TM/Landsat-5 image, acquired on September $21^{\text {st }}, 1998$ with nominal resolution of $30 \mathrm{~m}$ (Fig. 2) (GHERARDI et al., 1999; MORELLI, 2000). The thematic map generated from this classification was corrected using fieldwork and GPS (Global Positioning System) data. Because the thematic map had more classes than desired, a remapping was necessary, in order to obtain only two classes: reef and water. However, the class reef did not distinguish between emergent and submerse reefs, which made the validation more complicated, since the present work aimed to identify only emergent reefs. 


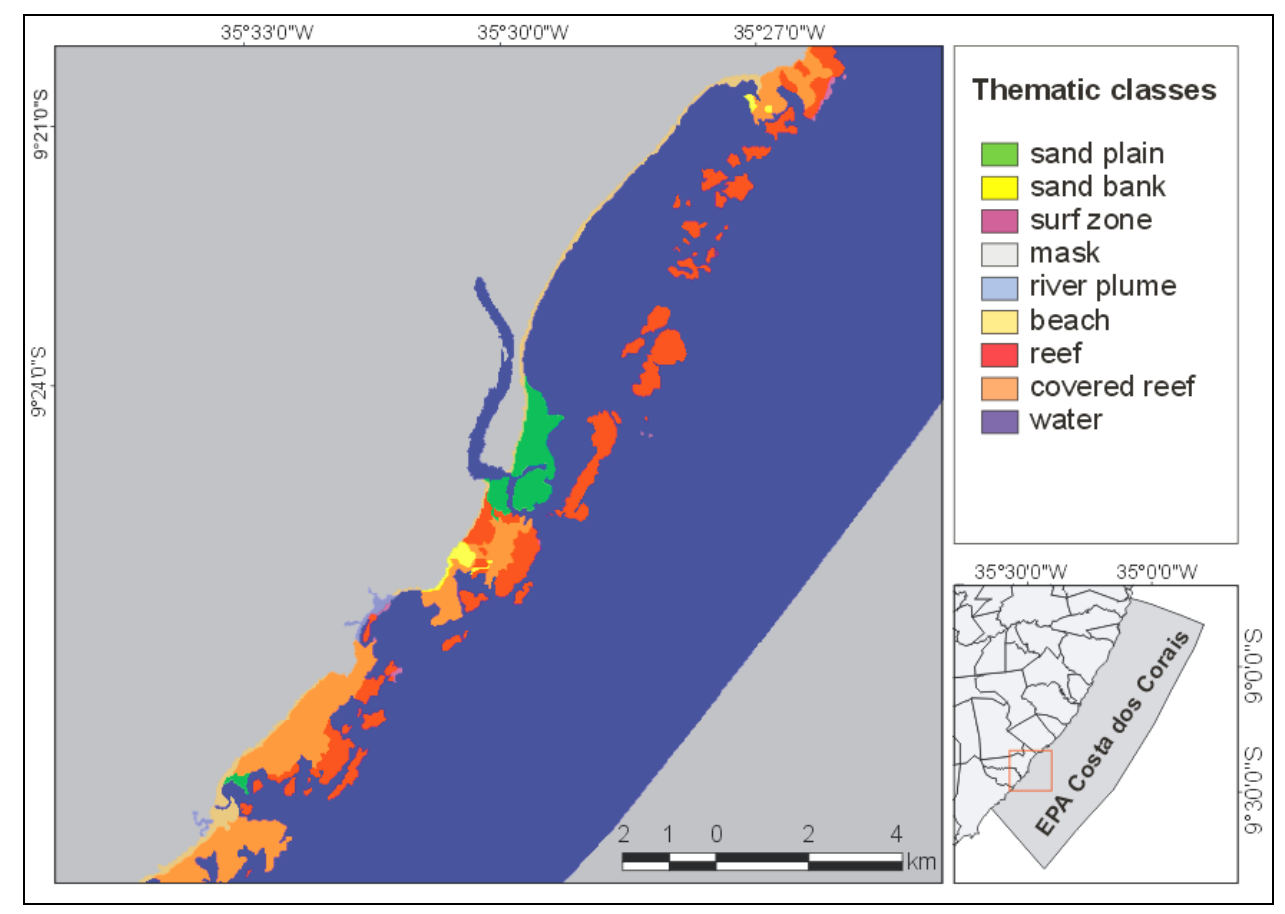

Fig. 2. Thematic map of the TM/Landsat-5 classification (MORELLI, 2000).

SAR Image Pre-processing

Initially, different filters were tested to remove speckle noise, with windows of $3 \times 3,5 \times 5$, and 7x7. The filters tested were: Gamma MAP, Sharp, Prewitt, Lee, Kuan, Frost, Enhanced Frost, Block Average, Edge Detection and Sobel Edge (FROST et al., 1982; KUAN et al., 1985; LEE, 1980; LOPES et al., 1990; LOPES et al., 1993). All these filters are available on the software package EASI/PACE (PCI, 1995), which was used on the image pre-processing. The only filter that was applied on a different software was the filter Coefficient of Variation, which was realized on the software ENVI (ENVI, 1999).

The image was then linearly transformed from 16 bits to 8 bits and then imported into the SPRING software, version 3.2 (CÂMARA et al., 1996), where the image was georeferenced, segmented, and classified. The georeferencing was performed by co-registration with a previously georeferenced TM/Landsat-5 image with UTM projection and datum SAD69. Six control points were used and the nearest neighbor interpolation method was applied, due to its simplicity and because this method does not modify the gray levels (CÂMARA et al., 1996). The resulting RMS from the georeferencing was 0.57 pixels, corresponding to $4.56 \mathrm{~m}$ in the RADARSAT image.

\section{SAR Image Classification}

The classification was based on the region growing technique from a pre-segmented image. With this method, polygons are grouped from individual pixels growing interactively until all pixels are processed (BEAUCHEMIN et al., 1998). When dealing with SAR images this method is better than the classification method based on pixels due to the presence of speckle noise (LOBO et al., 1996).

The filtered SAR image was segmented with a range of thresholds of similarity digital number, between 4 and 30, and area size, between 5 and 50 . The combinations were tested in order to obtain the best segmentation of the targets of interest.

The classification procedure was carried out on the segmented SAR image. In contrast to the segmentation, where a pre-filtered image was used for the classification, the reference data was obtained from a raw SAR image, aiming to extract the original radiometric information. For the classification, different acceptance thresholds (75\% and 99\%) were also tested with different segmented images.

The thematic map resulting from the classification was then edited in order to remove confusion with speckle noise, foam from waves, and misclassification along the coastline, especially due to the presence of peers, which have a similar response as 
the reefs. To assist the thematic map edition, the $\mathrm{TM} /$ Landsat-5 reference image was used.

\section{Accuracy Assessment}

The classification accuracy was assessed based on the Landsat-5 TM thematic map (GHERARDI et al., 1999; MORELLI, 2000). Error matrixes were built, on a category-by-category basis, to establish the relationship between the known reference data (TM thematic map) and the edited and non-edited results of the classified SAR image (LILLESAND; KIEFER, 1994).

There are two known accuracies on the error matrix. The producer's accuracies indicate how well a given set of reference pixels are accurately classified (LILLESAND; KIEFER, 1994). They result from dividing the number of correctly classified pixels in each category by the total number of pixels of the reference for that category (the column total). In other words, they represent the percentage of pixels of the reference map that were correctly identified by the classification. The user's accuracy, on the other hand, indicates the probability that a pixel classified into a given category actually represents that category on the reference map (LILLESAND; KIEFER 1994).

Because the category reefs on the reference map did not distinguish emergent reefs from the submerged reefs the classification matrix could not be fully assessed. Nevertheless, the error matrix can give an approximation of the ability of the classifier to classify emergent reefs.

\section{Results \\ Filters}

The filters that presented the best results, in decreasing order, following the criteria of border preservation and speckle suppression were: Kuan, Gamma MAP, Lee, Frost, Enhanced Frost, Block Average and Sharp. The filters Border Detection and Variation Coefficient also removed the speckle noise; however, the performance of border preservation was not as good as the previously mentioned filters. The filters Sober Edge and Prewitt did not give satisfactory results.

The $3 \times 3$ window had the best performance, because it significantly reduced speckle noise, while preserving the edges. Filters with larger windows reduced speckle even more, however, the edges got blurred.

Figures $3 \mathrm{a}$ and $3 \mathrm{~b}$ show a part of the scene before and after the filter Kuan was applied with window $3 \times 3$, respectively.
A

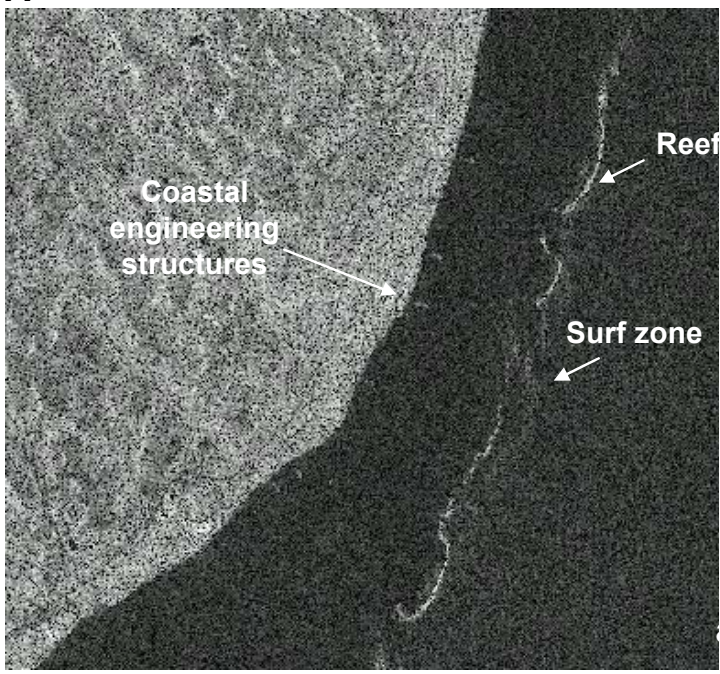

\section{B}

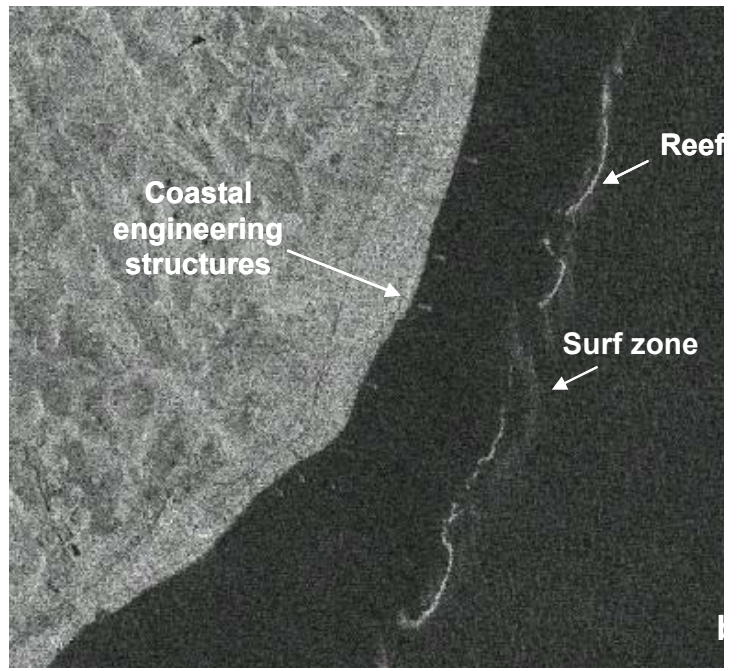

Fig. 3. A) Raw SAR/RADARSAT-1 image; B) SAR/RADARSAT-1 image filtered by the Kuan filter with a $3 \times 3$ window. 
Segmentation

For the image segmentation, an image previously filtered by a Kuan filter, with a $3 \times 3$ window was used. The thresholds of area and similarity that best represented the reefs were 5 and 10, respectively (Fig. 4).

\section{Classification}

The thematic map obtained from the classification with the threshold of acceptance of $75 \%$ had an accuracy of $34.6 \%$ for the class reef, and $92,4 \%$ for the class water (Fig. 5; Table 1). The reference accuracy was $6.6 \%$ for reefs and 98.9 for water.

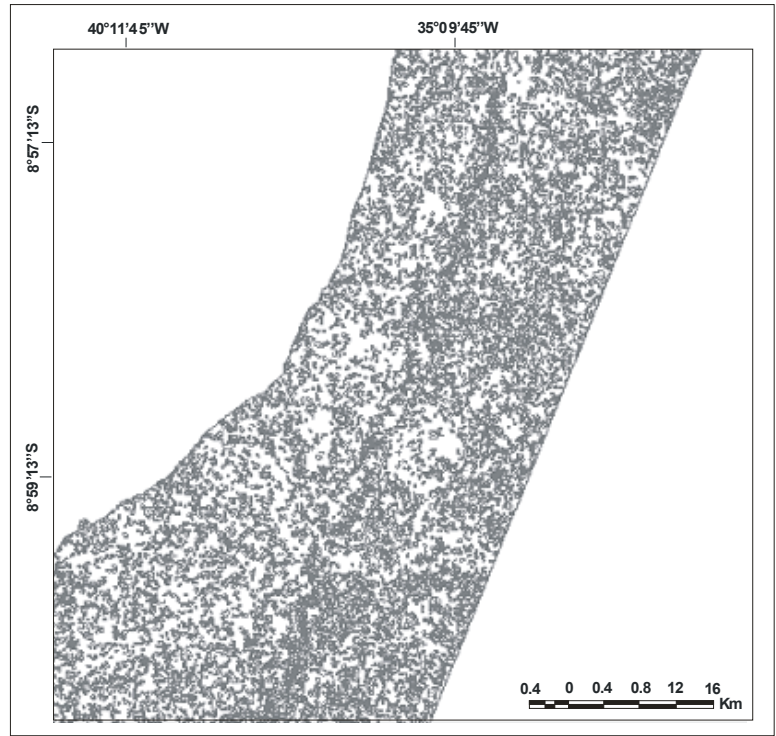

Fig. 4. Segmented image with the thresholds of area and similarity of 5 and 10 , respectively.

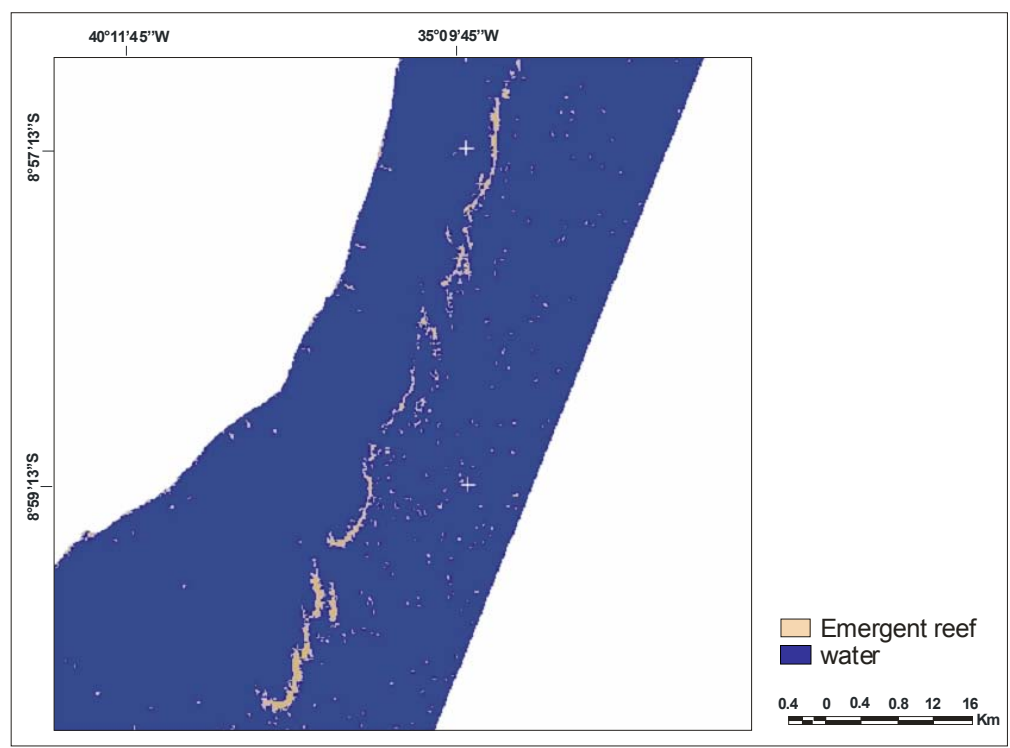

Fig. 5. Thematic map with acceptance threshold of $75 \%$. 
Table 1. Error matrix between the reference thematic map (TM) and the image classification (SAR), with the acceptance threshold of $75 \%$.

\begin{tabular}{|c|c|c|c|c|c|}
\hline & & \multicolumn{4}{|c|}{ Reference data (TM) } \\
\hline & 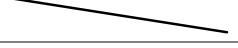 & Reef & Water & Row Total & User's accuracy (\%) \\
\hline \multirow{4}{*}{ 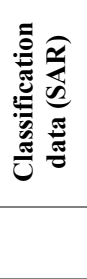 } & Reef & 15277 & 28890 & 44167 & 34.6 \\
\hline & Water & 214391 & 2601857 & 2816248 & 92.4 \\
\hline & Column Total & 229668 & 2630747 & 2866276 & \\
\hline & $\begin{array}{c}\text { Producer's } \\
\text { accuracy (\%) }\end{array}$ & 6.6 & 98.9 & & \\
\hline
\end{tabular}

After the edition of the classification with the $75 \%$ acceptance threshold, the classification accuracy of reefs rose substantially to $79.4 \%$; however, the class water had little change (Fig. 6; Table 2). The reference accuracy also remained at $6.6 \%$ for reefs, while the class water reached $100 \%$ accuracy.

With a threshold of $99 \%$, the accuracy of the classification was $59 \%$ (Fig. 7; Table 3), which is a better performance in respect to the $75 \%$ threshold (Table 1). However, there was a significant decrease on the reference accuracy for the reef class, which lowered from $6.6 \%$ to $2 \%$ (Tables $1 ; 3)$.

After the edition, the classification accuracy of the reef class rose to $87.2 \%$; however, the reference accuracy remained on the $2 \%$ (Fig. 8 ; Table 4 ).

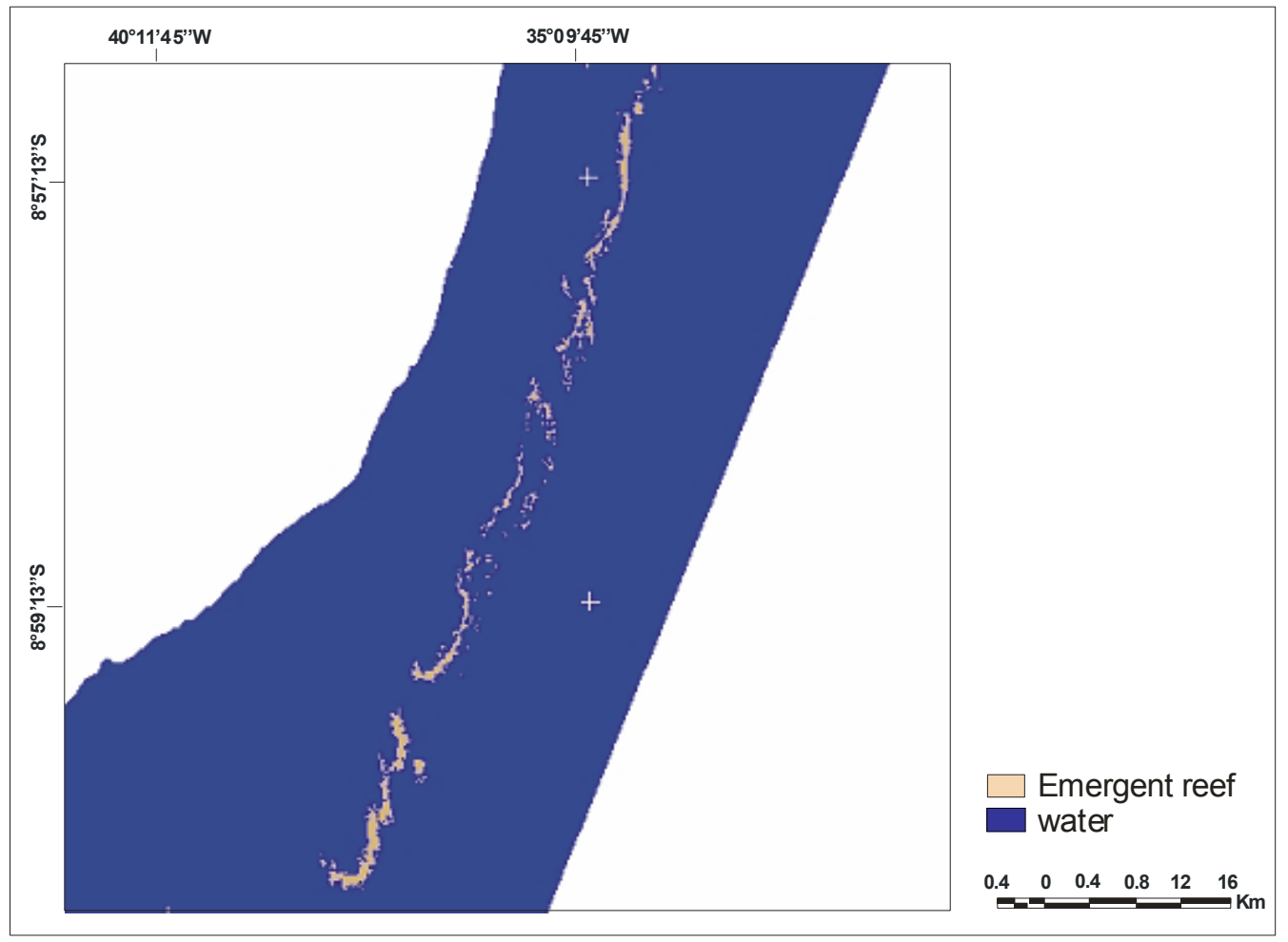

Fig. 6. Thematic map with acceptance threshold of $75 \%$. 
Table 2. Error matrix between the reference thematic map (TM) and the classified image (SAR) with the acceptance threshold of $75 \%$.

\begin{tabular}{|c|c|c|c|c|c|}
\hline & & \multicolumn{4}{|c|}{ Reference data (TM) } \\
\hline & - & Reef & Water & Total & User's accuracy $(\%)$ \\
\hline \multirow{4}{*}{ 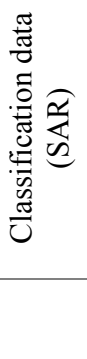 } & Reef & 15099 & 3927 & 19026 & 79.4 \\
\hline & Water & 214569 & 2626820 & 2841389 & 92.5 \\
\hline & Total & 229668 & 2630747 & 2866276 & \\
\hline & $\begin{array}{c}\text { Producer's } \\
\text { accuracy }(\%)\end{array}$ & 6.6 & 100 & & \\
\hline
\end{tabular}

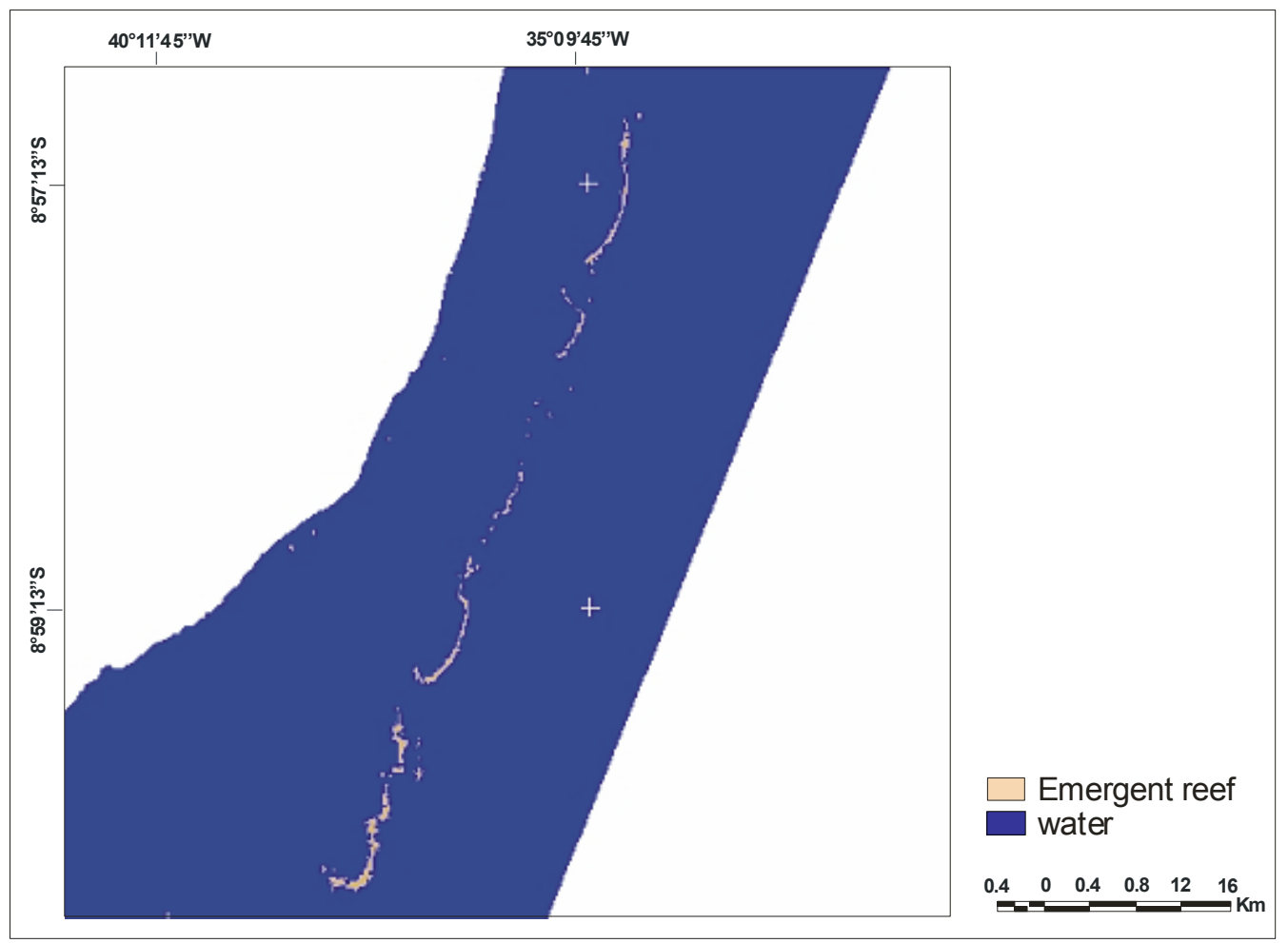

Fig. 7. Thematic map with acceptance threshold of $75 \%$. 
Table 3. Error matrix between the reference thematic map (TM) and the classified image (SAR) with the acceptance threshold of $75 \%$.

\begin{tabular}{|c|c|c|c|c|c|}
\hline & & \multicolumn{4}{|c|}{ Reference data (TM) } \\
\hline & $=$ & Reef & Water & Total & User's accuracy (\%) \\
\hline \multirow{4}{*}{ 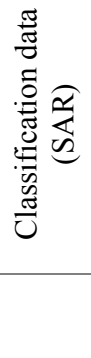 } & Reef & 4600 & 3195 & 7795 & 59.0 \\
\hline & Water & 225068 & 2627552 & 2852620 & 92.1 \\
\hline & Total & 229668 & 2630747 & 2866276 & \\
\hline & $\begin{array}{c}\text { Producer's } \\
\text { accuracy }(\%)\end{array}$ & 2.0 & 99.9 & & \\
\hline
\end{tabular}

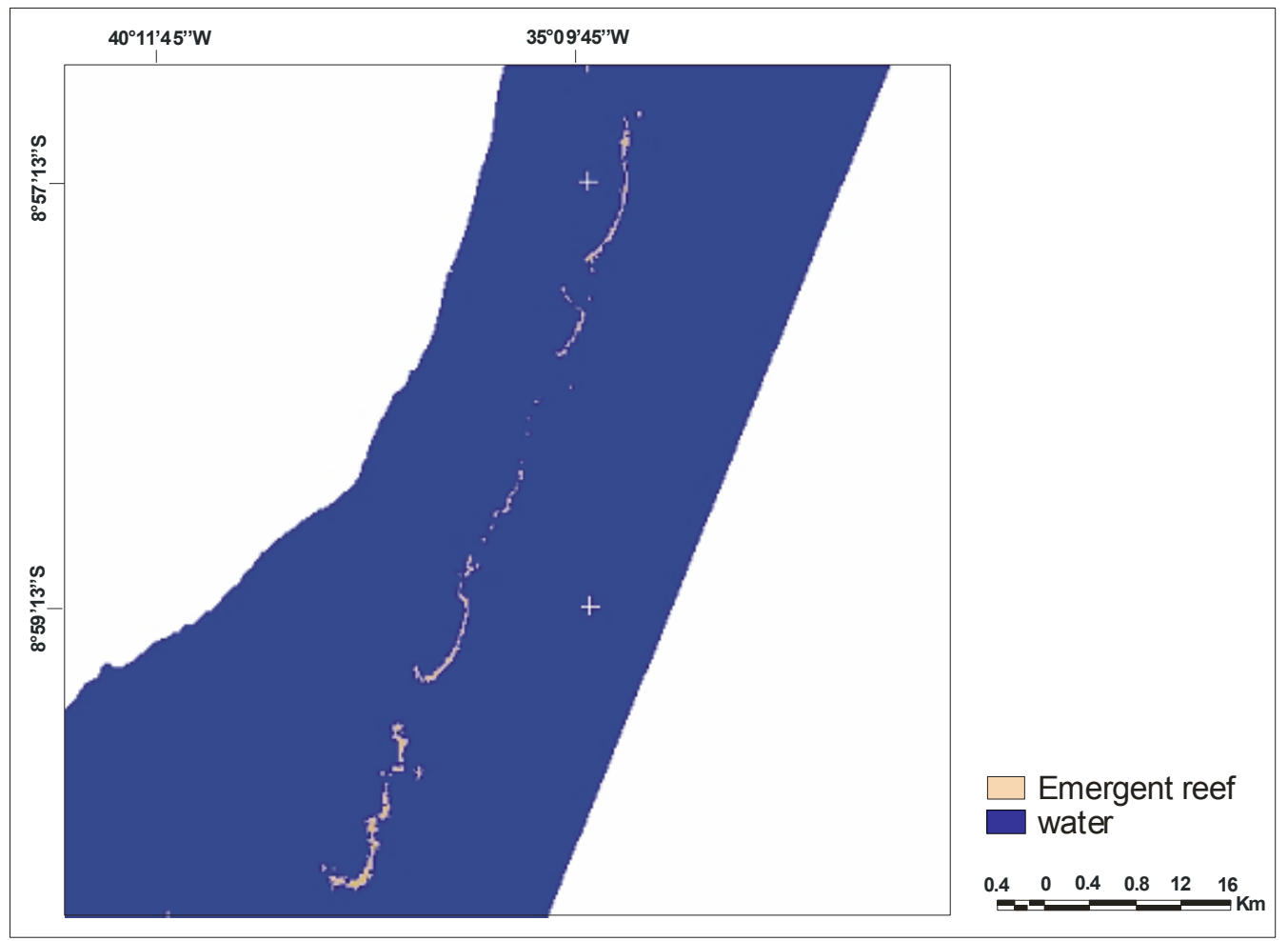

Fig. 8. Thematic map with acceptance threshold of $75 \%$. 
Table 4. Error matrix between the reference thematic map (TM) and the classified image (SAR) with the acceptance threshold of $75 \%$.

\begin{tabular}{|c|c|c|c|c|c|}
\hline & & \multicolumn{4}{|c|}{ Reference data (TM) } \\
\hline & 3 & Reef & Water & Total & User's accuracy (\%) \\
\hline \multirow{4}{*}{ 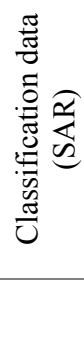 } & Reef & 4591 & 673 & 5264 & 87.2 \\
\hline & Water & 225070 & 2630074 & 2855144 & 92.1 \\
\hline & Total & 229661 & 2630747 & 2866276 & \\
\hline & $\begin{array}{c}\text { Producer's } \\
\text { accuracy }(\%)\end{array}$ & 2.0 & 100 & & \\
\hline
\end{tabular}

\section{Discussion and Conclusion}

Emergent coral reefs can be detected by SAR images due to the differences of the way radar wave interacts with sea surface and emergent reefs. Smooth sea surfaces are specular reflectors, reflecting the microwave away from the sensor with low backscattering, thus appearing in dark tonalities. On the other hand, emergent coral reefs are diffuse scatters and large amounts of the microwave energy are returned to the sensor, appearing in intermediate gray tonalities. This yields a high contrast between water and reef surfaces. However, as the sea surface roughness increases (ie. wind, waves and currents) the amount of radar backscattering also increases (BAGHDADI et al., 2007). Therefore, the presence of waves at the time of image acquisition could have caused some confusion between the backscattered signal from foam and emergent reef, misleading the classification of water pixels as reef.

The coastal reefs at Costa dos Corais form straight, long lines parallel to the shoreline (CASTRO, 2001). Even though the emergent reefs are relatively narrow features, the fine beam mode showed to have sufficient resolution to identify the reefs. The F3 incident beam angle $\left(41-44^{\circ}\right)$ of the image used on the present research was also adequate to identify the reefs, once large incident angles $\left(>30^{\circ}\right)$ are considered optimal for land-sea discrimination when compared to shallow angles (BAGHDADI et al., 2004, 2007). Furthermore, the sensor's look direction is practically perpendicular to the orientation of the reefs which also enhances their detection (TRAVAGLIA et al., 2004).

The filters that had the best performance on speckle noise suppression and border preservation were the adaptive filters such as Kuan, Gamma MAP, Lee, Frost and Enhanced Frost. These are the most commonly applied filters for speckle suppression found on the literature, due to their capacity to adequately average homogeneous areas and better preserve, at the same time, edges and textural information (LOPES et al., 1990; XIAO et al., 2003). The filter selected for the image segmentation was the Kuan filter with a $3 \times 3$ window, which visually presented the best results.

For the segmentation, the low values for the similarity and area thresholds used (5 and 10 , respectively) are justified by the reduced dimensions and the strait and elongated forms of the reefs (MORELLI, 2000).

The $75 \%$ classification threshold had lower user's accuracy and a better producer's accuracy than the $99 \%$ threshold. However, it may be possible that some pixels that were classified as reef were in fact foam from waves (water). These waves do occur on the east side of the reefs and can also be observed by other medium spatial resolution sensors like the HRV/SPOT, as pointed out by MORELLI (2000). Because waves have different structural pattern than reefs on the image and occur mostly on the east of the reefs, theses pixels can be identified and much of the error was suppressed after editing the misclassified pixels. However, as the foam gets closer to the reefs it becomes more difficult to distinguish them from reefs. Nevertheless, this type of confusion is also a problem for coastline detection by optic sensors, which is wavelength dependent (FROUIN et al., 1996).

The higher accuracy obtained by the $99 \%$ threshold is because it is more restrictive. Thus, this threshold made less confusion between breaking 
waves and reefs; but it is also possible that some pixels that were classified as water were in fact reefs. This reflects on the lower reference accuracy obtained by this threshold. However, the classification accuracy could not be fully assessed due to several factors regarding the reference map used, which was based on a TM/Landsat image. The reference did not distinguish between emergent and submerged reef, and that is the main reason that the producer's accuracy was so low for both thresholds. Also, the tide level was $1.39 \mathrm{~m}$, which is in between low and high tide. If the image had been acquired at low tide the producer's accuracy should increase. Besides, the TM sensor has a coarser accuracy $(30 \mathrm{~m})$ and possibly could have some sort of confusion with foams. Therefore, future works should be done with extensive fieldwork for accuracy assessment, and intercomparisons between SAR and optical sensor for intertidal and emergent reefs should be encouraged.

Even though it is not possible to distinguish with SAR/RADARSAT-1 fine mode images the different emergent coral reef habitats, such as the reefcrest and reef-flat, where carbonate sand and reef rubble deposits can develop, our results highlight their potential to detect emergent coral reefs.

With the launch of RADARSAT-2, scheduled for March 2007, it will be possible to identify reefs with spatial resolution of up to $3 \mathrm{~m}$. Moreover, the use of multipolarization images should enhance the discrimination of different features associated to reef habitats. It is also expected a significant improvement in the distinction of emergent reefs from breaking waves and the delineation of emerging reef crests. Besides, cloud cover is not an obstacle to SAR RADARSAT-2, and the ability of left-right look directions increases the possibilities of feature identification and revisit time, which is particularly important in order to obtain images in optimal tide levels.

With multitemporal images acquired on different tide levels, topography of intertidal and emergent reefs can also be estimated, as already shown by YAMANO et al. (2006) for different optical sensors. The authors found that the Terra ASTER sensor showed to be the best cost-effective sensor for extracting waterlines, when comparing to the other satellite sensors IKONOS and Landsat $\mathrm{ETM}^{+}$. They also pointed out the promising application of passive SAR sensor, whose potentials were shown on this paper.

Moreover, the methodology presented could be tested for the identification of other targets on coastal waters, such as groins, jetties, peers, fish pens, oyster beds and others. TRAVAHLIA et al. (2004) showed the applications of SAR images for mapping small fish cages, pens, traps and ponds with good precision using a visual classification. Another approach was applied by SUGA et al. (1999), who used a series of spatial filters to map oyster beds from SAR/RADARSAR and HRV/SPOT images. A possibility is to apply unsupervised classification methods based on image segmentation, as presented on the present work, for the identification of other coastal targets.

\section{ACKNOWLEDGEMENTS}

Frederico M. Rudorff thanks the National Council for Technological and Scientific Development $(\mathrm{CNPq})$ for the scholarship which allowed the elaboration of this work during the International Course on Remote Sensing at INPE.

\section{REFERENCES}

AHMAD, W.; NEIL, D. T. An evaluation of Landsat Thematic Mapper (TM) digital data for discriminating coral reef zonation: Heron Reef (GBR). Int. J. Remote Sens., v.15, n. 13, p. 2583-2597, 1994.

ANDRÉFOUËTA, S.; KRAMERB, P.; TORRESPULLIZAC, D.; JOYCED, K. E.; HOCHBERGE, E. J.; GARZA-PÉREZF, R.; MUMBYG, P. J.; RIEGLH, B.; YAMANOI, H.; WHITEJ, W. H.; ZUBIAK, M.; BROCKC, J. C.; PHINND, S. R.; NASEERL, A.; HATCHERL, B. G.; MULLER-KARGERA, F. E. Multisite evaluation of IKONOS data for classification of tropical coral reef environments. Remote Sens. Env., n. 88 , p. $128-143,2003$.

BAGHDADI, N.; GRATIOT, N.; LEFBVRE, J. P.; OLIVEROS, C.; BOURGUIGNON, A. A coastline and mudbank monitoring in French Guiana: contributions of radar and optical satellite imagery. Can. J. Remote Sens., v. 30, p. 109-122, 2004.

BAGHDADI, N.; PEDREROS, R.; LENOTRE, N.; DEWEZ, T.; PAGANINI, M. Impact of polarization and incidence of the ASAR sensor on coastline mapping: example of Gabon. Int. J. Remote Sens., v. 28, n. 17, p. 3841-3849, 2007.

BEAUCHEMIN, M.; THOMSON, K. P. B.; EDWARDS, G. On Nonparametric edge detection in multilook SAR images. IEEE Trans. Geosci. Remote Sens., v. 36, n. 5, p. 1826-1829, 1998

BRAGA, C. Z. F.; GHERARDI, D. F. M. Mapeamento de recifes costeiros utilizando imagens orbitais. In: SIMPÓSIO BRASILEIRO DE SENSORIAMENTO REMOTO, 10., 2001. Foz do Iguaçu, Proceedings... São Paulo: Fábrica da Imagem, 2001. 13 p.

CÂMARA, G.; SOUZA, R. C. M.; FREITAS, U. M.; GARRIDO, J. SPRING: Integrating remote sensing and GIS by object-oriented data modelling. J. comput. Graphics, v. 20, n. 3, p. 395-403, 1996.

CASTRO, C. B.; PIRES, D. Brazilian coral reefs: what we already know and what is still missing. Bull. mar. Sci., v. 2 , n. 69 , p. $357-71,2001$.

CLARK, J. R. Coastal zone management Handbook. Boca Raton, FLA: CRC Press., 1996. 720 p.

ENVI, Environment for visualizing images, Lafayette: Research Systems, Inc. 1999. 
FROST, V. S.; STILES, J. A.; SHANMUGAN, K. S.; HOLTZMAN, J. C. A model for radar images and its applications to adaptive digital filtering of multiplicative noise. Trans. Patt. Anal. Mach. Intel., PAMI-4, n. 2, p. 157-166, 1982.

FROUIN, R.; SCHWINDLING, M.; DESCHAMPS, P.-Y. Spectral reflectance of sea foam in the visible and nearinfrared: In situ measurements and remote sensing implications. J. Geophys. Res., v. 101(C6), p. 14361$14371,1996$.

GALY, H. M.; SANDERS, R. A. Using synthetic aperture radar imagery for flood modelling. Trans. in GIS, v. 6, n. 1, p. 31-42, 2002.

GHERARDI, D. F. M. ; BRAGA, C. Z. F.; MORELLI, F. Reef conservation in Brazil: remote sensing and ground truthing. Reef Encounter, v. 26, p. 32, 1999.

GREEN, E. P. M. P. J.; EDWARDS, A. J.; CLARK, C. D. Remote sensing Handbook for tropical coastal management. Paris: United Nations Educational, 2000. p. $129-175$.

JOHANNESSEN, O. M.; SANDVEN, S.; JENKINS, A. D. DURAND, D.; PETTERSSON, S. H.; ESPEDAL, H.; EVENSEN, G.; HAMRE, T. Satellite earth observation in operational oceanography. Coast. Eng., v. 41, p. 155176,2000

KUAN, D. T.; SAWCHUK, A. A.; STRAND, T. C.; CHAVEL, P. Adaptative noise smoothing filter for images with signal dependent noise. Trans. Patt. Anal. Mach. Intel., PAMI -2, p. 165-177, 1985.

KUCHLER, D. A.; JUPP, D. L. B.; CLAASEN, D. R.; BOUR, W. Coral reef remote sensing applications. Geocart. int., v. 4, p. 3-15, 1986.

LEE, S. J. Digital image enhancement and noise filtering by use of local statistics. Trans. Patt. Anal. Mach. Intel., v.2, n. 2, p. 165-168, 1980.

LILLESAND, T. M.; KIEFER, R. W. Remote sensing and image interpretation. New York: Wiley \& Sons, 1994. $724 \mathrm{p}$.

LOBO, A.; CHIC, O.; CASTERAD, A. Classification of Mediterranean crops with multisensor data : per-pixel versus per-object statistics and image segmentation. Int. J. Remote Sens., v.17, n. 2, p. 2385-2400, p. 1996.

LOPES, A.; TOUZI, R.; NEZRY, E. Adaptive speckle filters and scene heterogeneity. IEEE Trans. Geosci. Remote Sens., v. 28, n. 6, p. 992-1000, 1990.

LOPES, A.; NEZRY, E.; TOUZI, R.; LAUR, H. Structure detection and statistical adaptive speckle filtering in SAR images. Int. J. Remote Sens., v. 14, n. 9, p. 1735- 1758, 1993.

MAIDA, M.; FERREIRA, B. P. Coral reefs of Brazil: an overview. In: INTERNATIONAL CORAL REEF SYMPOSIUM, 8. 1997, Panama City. Proceedings... International Society for Reef Studies, 1997. p. 263 274.

MOBERG, F.; FOLKE, K. Ecological goods and services of coral reef ecosystems. Ecol. Econ., v. 29, p. 215-223, 1999.

MORELLI, F. Mapping of coastal reefs of Paripueira (AL) using LANDSAT TM and HRV SPOT image classification. 2000. 78 p. (Master Thesis in Remote Sensing) - Instituto Nacional de Pesquisas Espaciais, São José dos Campos, SP. In Portuguese. 2000.
PCI, Easi-Pace Software. Richmont: PCI Geomatics. 1995.

PURKIS, S. J. A "Reef-Up" approach to classifying coral habitats from IKONOS imagery. IEEE Trans. Geosci. Remote Sens., v. 43, n.6, p. 1375-1390, 2005.

RIEGL, B. M.; PURKIS, S. J. Detection of shallow subtidal corals from IKONOS satellite and QTC View (50, 200 $\mathrm{kHz}$ ) single-beam sonar data (Arabian Gulf; Dubai, UAE). Remote. Sens. Environ., v. 95, p.96-114, 2005.

RSI. RADARSAT Data Products Specifications. RADARSAT International (RSI). Richmond: RSI, RSIGS-026, 1997. 148 p.

SHERBININ, A.; RAUSTIALA, K.; KLINE, K. Remote sensing data: Valuable support for environmental treaties. Environ., v. 44, n. 1, p.20-31, 2002.

SOLER, L. D. S. Oil slick detection on sea surface by textural classification of sinthetic aperture radar images (RADARSAT-1). 2000. 167 p. (Master Thesis in Remote Sensing) - INPE, São José dos Campos, SP. 2000.

STOFFLE, R. W.; HALMO, D. B.; WAGNER, T. W.; LUCZKOVICH, J. J. Reefs from space: satellite imagery, marine ecology, and ethnography in the Dominican Republic. Hum. Ecol: An Interdisciplinary Journal, v. 22, n.3, p. 355-378, 1994.

SUGA, Y.; OGURO, Y.; TAKEUCHI, S. Detection of oyster beds using Sar and Optical Sensor Data. In: ASIAN CONFERENCE ON REMOTE SENSING, 20., 1999, Hong Kong. Proceedings... GIS Development, 1999. p. 1-2. TRAVAGLIA, C.; PROFETI, G.; AGUILARMANJARREZ, J.; LOPEZ, N. Mapping coastal aquaculture and fisheries structures by Satellite Imaging Radar: Case Study of the Lingayen Gulf, the Philippines. FAO Fish. tech Pap., 2004. 45 p.

VAN DER SANDEN, J. J.; ROSS, S. G. Applications potential of RADARSAT-2: A preview. Report for the Canadian Space Agency. Ottawa: CCRS, 2001. 80 p.

XIAO, J.; Li, J.; MOODY, A. A detail-preserving and flexible adaptive filter for speckle suppression in SAR imagery. Int. J. Remote Sens., v. 24, n. 12, p. 24512465, 2003.

YAMANO, H.; SHIMAZAKI, H.; MATSUNAGA, T.; ISHODA, A.; MCCLENNEN, C.; YOKOKI, H.; FUJITA, K.; OSAWA, Y.; KAYANNE, H. Evaluation of various satellite sensors for waterline extraction in a coral reef environment: Majuro Atoll, Marshall Islands. Geomorph., v. 82, p. 398-411, 2006.

(Manuscript received 23 March 2007; revised 05 October 2007; accepted 12 November 2007) 